IFAS Extension

\title{
Making Good Decisions: Television, Learning, and the Cognitive Development of Young Children ${ }^{1}$
}

David C. Diehl and Stephanie C. Toelle ${ }^{2}$

"If the television craze continues with the present level of programs, we are destined to have a nation of morons."

\section{- Daniel Marsh, 1950}

As evidenced by this quote from 1950, Americans have been concerned about the effects of television for more than a half century. From the very beginning, television captured the American imagination and became an important influence in the lives of our families. Today, virtually every family in the U.S. has at least one television and most children and adults alike watch TV on a daily basis.

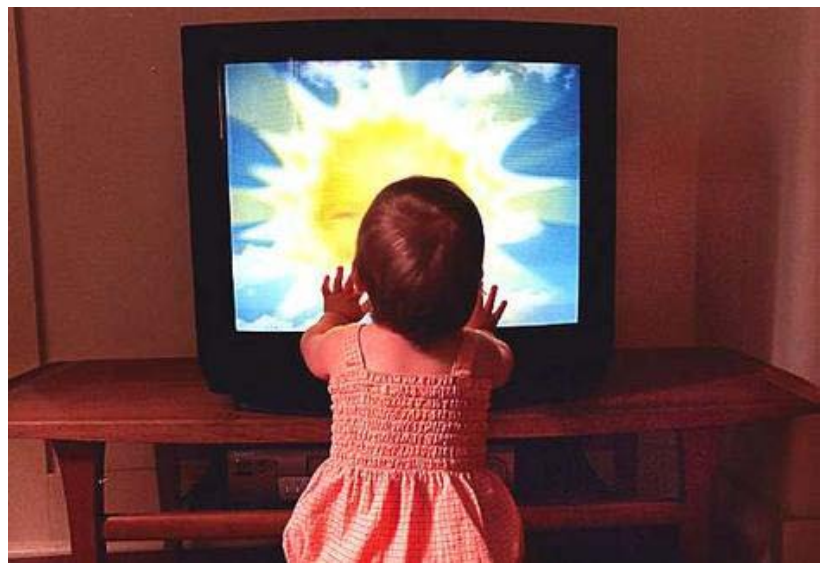

Figure 1: Television shapes children's learning. (Source: Sydney Morning Herald)

There is no denying the prevalence of television in our lives and its potential to shape children's learning. Has Daniel Marsh's prediction come true-are we a nation of morons because of television's influence? How does television affect our children? Do children learn from television? Does it affect their school performance? What can parents do to maximize the benefits of television and minimize any harm?

Parents have all of these questions and more as they contemplate how television can help or interfere with their children's learning and academic development. This paper will explore how television affects the learning of young children (ages 0-6) and how it impacts their cognitive development and later academic performance.

\section{Background}

While researchers have long been interested in the effects of television on the American family, recent research and policy efforts have increasingly focused on the effects of television on young children. In 1999, The American Academy of Pediatrics (AAP) recommended that children under two years of age should watch no television at all and that children over two should watch no more than one to two hours of highquality educational programming. ${ }^{1}$

While content for preschool-age children such as Sesame Street has been around for decades, television and video content designed to reach infants is much newer. During the past decade programs and videos specifically designed for infants have been introduced and popularized,

1. This publication is FCS2291, one of a series of the Department of Family, Youth and Community Sciences, Florida Cooperative Extension Service, Institute of Food and Agricultural Sciences, University of Florida. Publication: December 2008. Please visit the EDIS Web site at http://edis.ifas.ufl.edu

2. $\quad$ David C. Diehl, Ph.D., assistant professor, Department of Family, Youth and Community Sciences, Cooperative Extension Service, Institute of Food and Agricultural Sciences, University of Florida, Gainesville, 32611. Stephanie C. Toelle, extension agent IV, Duval County Extension, Jacksonville, FL.

The Institute of Food and Agricultural Sciences (IFAS) is an Equal Employment Opportunity-Affirmative Action Employer authorized to provide research, educational information and other services only to individuals and institutions that function without regard to race, creed, color, religion, age, disability, sexual orientation, marital status, national origin, political opinions, or affiliation. For information on obtaining other extension publications, contact your county Cooperative Extension Service office. Florida Cooperative Extension Service/Institute of Food and Agricultural Sciences/University of Florida/Larry R. Arrington, Dean. 
generating sales of about $\$ 100$ million in $2004 .^{2}$

Products such as the Baby Einstein series and

Brainy Babies, among others, were specifically

designed to reach infants and are marketed as

educational materials to optimize child

development.

While marketed as educational, there is little scientific evidence that these materials foster learning in very young children. A thorough review of educational media for babies and toddlers concluded that "there are no published studies on cognitive outcomes from any of the educational videos, computer software programs, or video game systems currently on the market for children ages 0-6 years." 3

All of this attention means that parents need to think carefully about the role of television in the lives of their infants, toddlers, and preschoolers.

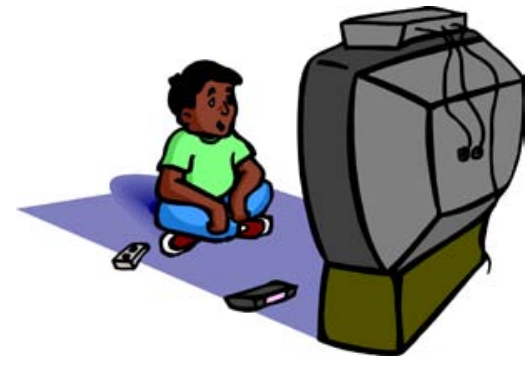

Parents should proactively create an approach to television watching that works for their family.

\section{Young Children's Television Exposure}

Despite the AAP's recommendation that families limit children's television viewing, a recent study found that $83 \%$ of children under the age of two use screen media (television, videos, DVDs) on a typical day and $66 \%$ of children aged six months to six years watch television every day. ${ }^{4}$ Another study found that, on average, children age six and under watch television for more than two hours per day. ${ }^{5}$

While many studies focus on how much children's programming children are watching, others are also starting to emphasize that children are exposed to significant amounts of adult television because the TV is often on in the background. ${ }^{6}$ All in all, television and videos are quite common in the lives of young children and can influence their development.

\section{How Children Learn}

To guide parents in their decisions about children's media use, it is useful to start with what we know about how young children grow and learn in positive ways. What do we know about how infants, toddlers, and young children learn and develop the social, emotional, and cognitive skills that will help them navigate this remarkably complex world? Research on early brain development has established that while babies are born with billions of brain cells, positive interactions with their environment are critical to the development of neural pathways that enable positive development. ${ }^{7}$

Some of the key things that infants, toddlers, and preschoolers need are:

- responsive, engaging, and stimulating interaction with their surroundings;

- exposure to language and sounds;

- adults who respond to their actions;

- the freedom and creativity that comes with play;

- the ability to explore the world and manipulate objects around them;

- guidance, structure, and support; and,

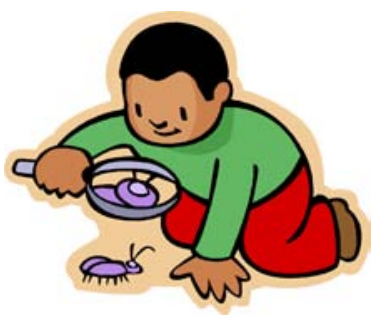

- praise, affection, and positive feedback.

All of these things are best provided by other human beings, especially parents who care deeply about them. How, then, does television influence how children learn?

\section{Effects on Children's Learning}

Research has shown that children's exposure to television during the preschool years is predictive of academic outcomes during adolescence. ${ }^{8}$ What is notable about this research, however, is that it is the kind of television that really matters. For example, adolescents whose parents permitted 
them to watched more educational programming when they were young are more likely to have higher grades, read more books, place greater value on achievement, and show more creativity. On the other hand, adolescents who watched more violent or purely 'entertainment' television when they were young tend to do less well in school and have lower grades overall. Parenting is a major factor in determining both television viewing patterns and educational outcomes because parents who encourage their children to watch educational programs are more likely to value education and support early learning in a variety of other ways as well.

Studies of educational television have also found benefits for young children. For example, Sesame Street, probably the most studied television program of all time, has been shown to have a variety of benefits for preschool children, including increases in vocabulary, ability to count, and general school readiness. ${ }^{9}$ Another study found that the benefits of educational television were most noticeable for those with moderate exposure, and for children who had the lowest levels of skills prior to viewing the program. ${ }^{10}$ The essential lesson here is that what children watch on television is an important predictor of later academic performance.

"With respect to development, what children watch is at least as important as, and probably more important than, how much they watch."

- The Future of Children, 2008

However, the benefits of educational programming are not equal for children of different ages. Research has found that children under two years of age are less able to systematically learn as much from television as they do from human interaction. ${ }^{11}$ While infants may pay attention to video images, most television does not offer the interactive and responsive content that infants need the most. While television may capture the attention of infants and toddlers, there is little evidence that it facilitates meaningful learning. In fact, research has found that television watching at very young ages is associated with lower levels of language development. ${ }^{12}$ As with other learning issues, it is likely that parents who restrict their children's television viewing at early ages are likely behave in ways that facilitate children's learning in other ways as well.

\section{Children's Reading and Language}

Development: Research has also found that children who live in households where the television is almost always on are at risk for reading difficulties. ${ }^{13}$ Children who live in "heavy-television" households where the television is on most or all of the time tend to watch more television and read less than other children. The children in these households also do not read as well, a finding that was true even when controlling for the educational level of the parents.

As with other studies, the

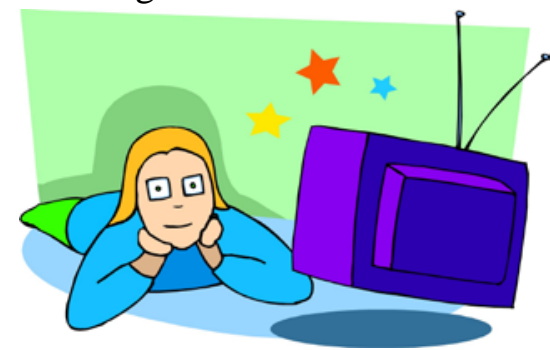
content of television is an important factor in determining whether the impact of television is positive or negative. For example, one study found that at 30 months, watching Dora the Explorer, Blue's Clues, Arthur, Clifford, Dragon Tales, or Sesame Street was associated with better language development, while watching Teletubbies was associated with lower language scores. ${ }^{14}$

Other research has found that for very young children (8-16 months), watching television and videos is related to lower language development, while this is not true of older preschoolers (17-24 months). ${ }^{15}$ It appears, then, that the most negative effects of television for children's language development takes place at the earliest ages. When determining television practices, parents need to consider not only the content of the programs, but also the age of their child.

Children's Attention Problems: Many parents worry that electronic media use might be related to children's attention spans and to attention 
deficit hyperactivity disorder (ADHD). Parents commonly observe that their child's attention is easily drawn to television for extended periods of time, despite other activities. The research findings, however, are inconclusive, with researchers disagreeing about whether television viewing is an important contributor to attention problems in children.

On the one hand, studies have found that the more television children watch at young ages, the more likely these children are to have attention problems in later childhood and adolescence. ${ }^{16}$ On the other hand, another recent study found no significant relationship between amount of television viewing at age five and attentional problems at age six. ${ }^{17}$ One possible explanation for this difference in findings is the age of the children being studied — some researchers believe that television may have its most negative impacts on children's attention when the children are very young and their brains are developing the capacity to process information. ${ }^{18}$

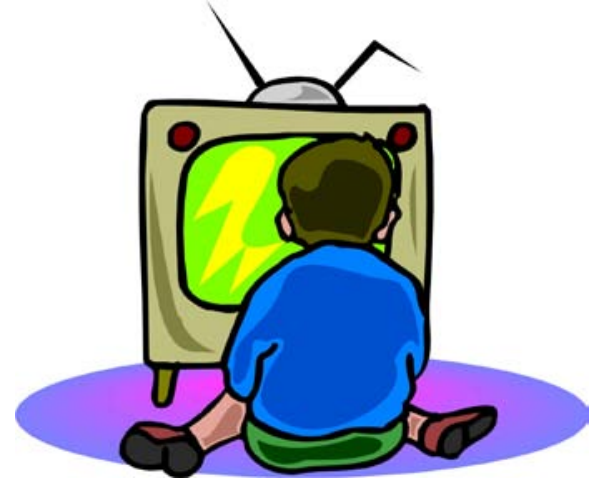

While the research is inconsistent, parents should be aware of the possibility that television may impact attention spans and contribute to attention problems, especially for very young children.

\section{What Parents Can Do ${ }^{19}$}

Parents are the primary forces for shaping media usage by their children. Parents who take an active role in creating rules, boundaries, and expectations for television use are more likely to have children who benefit from media time. Further, parents need to engage in constructive communication with their young children, establishing an ongoing dialogue about the messages children are receiving. Given all of the research described here, what can parents do to limit the negative effects and maximize the positive effects of television for young children?

- Choose positive programs that provide learning opportunities for children. Identify educational materials and encourage your children to watch them. To learn more about recommendations for educational materials, visit www.kidsfirst.org or www.commonsensemedia.org.

- Keep the television and computer out of children's rooms. Children who have a television in their room watch much more television than those who do not, and viewing tends to be unsupervised.

- Set rules and boundaries. Families that have clear rules and expectations about media usage are more likely to control the amount of media exposure as well as the quality.

- Create family alternatives to television time. It is important to take some of children's media time and replace it with other family activities that encourage bonding, activity, and quality time together. Consider art projects, outdoor activities, sports, reading together, music, games, and other family activities.

- Start creating strong learning habits early. Children learn habits at young ages, so if you turn on the television every morning, your child will come to expect this. Work hard to make sure you are creating expectations that you value and that contribute to learning. For more information on early learning issues, visit the Born Learning website at www.bornlearning.org or Parenting 24/7 at www.parenting247.org.

- Emphasize learning in all aspects of life, not just television. Parents should recognize that television is only one factor in shaping children's learning experiences. Parents should actively encourage learning in all phases of life-through play, stories, reading, music, and all of the every-day experiences where children interact with and learn about the world. 


\section{Endotes}

${ }^{1}$ American Academy of Pediatrics (1999). Media

education. Pediatrics, 104, 341-343.

${ }^{2}$ Khermouch, G. (2004). Brainier Babies? Maybe. Big Sales? Definitely. BusinessWeek.

${ }^{3}$ Garrison, M., Christakis, D. (2005). A teacher in the living room? Educational media for babies, toddlers and preschoolers. Kaiser Family Foundation.

${ }^{4}$ Rideout, V.,\& Hamel, E. (2006). The media family: Electronic media in the lives of infants, toddlers, preschoolers, and their parents. Menlo Park, CA: Kaiser Family Foundation.

${ }^{5}$ Roberts, D.F. \& Foehr, U.G. (2008). Trends in media use. The Future of Children 18(1),11-37.

${ }^{6}$ Anderson, D., \& Pempek, T. (2005). Television and very young children. American Behavioral Scientist, 48, 505-522.

${ }^{7}$ Ramey, C., \& Ramey, S. (2004)/ How children learn and how parents can help. Plain Talk: The Newsletter for the Center for Development and Learning, 9 (2), 1-11.

${ }^{8}$ Anderson, D., Huston, A., Schmitt, K., Linebarger, D, \& Wright, J. (2001). Early childhood television viewing and adolescent behavior: The recontact study. Monographs of the Society for Research in Child Development, 2001, 66(1, Serial No. 264).

${ }^{9}$ See Garrison, M., Christakis, D. (2005). A teacher in the living room? Educational media for babies, toddlers and preschoolers. Kaiser Family Foundation for a review of the research on the effects of Sesame Street.

${ }^{10}$ Baydar, N., Kagitcibasi, C., Kuntay, A., \& Goksen, F. (2008). Effects of an educational television program on preschoolers" Variability in benefits. Journal of Applied Developmental Psychology, 29, 349-360.

${ }^{11}$ See Wartella, E., \& Robb, M. (2007). Young children, new media. Journal of Children and Media, 1, 35-44. and Kirkorian, H., Wartella, E., \& Anderson, D. (2008). Media and young children's learning. The Future of Children, 18, p.42.

${ }^{12}$ Zimmerman, F., Christakis, D., \& Meltzoff, A. (2007). Associations between media viewing and language development in children under age 2 years. Journal of Pediatrics, 4, 364-368.,

${ }^{13}$ Vandewater, E., Bickham, D., Lee, J., Cummings, H., Wartella, E, \& Rideout, V. (2005). When the television is always on: Heavy television exposure and young children's development. American Behavioral Scientist, 48, 562-577.

${ }^{14}$ Linebarger, D., \& Walker, D. (2005). Infants' and toddlers' viewing and language outcomes. The American Behavioral Scientist, 48, 624-645.

${ }^{15}$ Zimmerman, F., Christakis, D., \& Meltzoff, A. (2007). Associations between media viewing and language development in children under age 2 years. Journal of Pediatrics, 4, 364-368.
${ }^{16}$ See Christakis, D., Zimmerman, F., DiGiuseppe, D., \& McCarty, A. (2004). Early television exposure and subsequent attentional problems in children. Pediatrics, 113, 708-713. and Landhuis, C., Poulton, R., Welch, D., \& Hancox, R. (2007). Does childhood television viewing lead to attention problems in adolescence? Results from a prospective longitudinal study. Pediatrics, 120, 532-537.

${ }^{17}$ Stevens, T., \& Mulsow, M. (2006). There is no meaningful relationship between television exposure and symptoms of Attention-Deficit/Hyperactivity Disorder. Pediatrics, 117, 665-672.

${ }^{18}$ Christakis, D., Zimmerman, F., DiGiuseppe, D., \& McCarty, A. (2004). Early television exposure and subsequent attentional problems in children. Pediatrics, 113, 708-713.

${ }^{19}$ These suggestions were adapted from a variety of resources, including: www.cmch.tv; www.mediafamily.org; and www.aap.org/advocacy/mediamatters.htm 